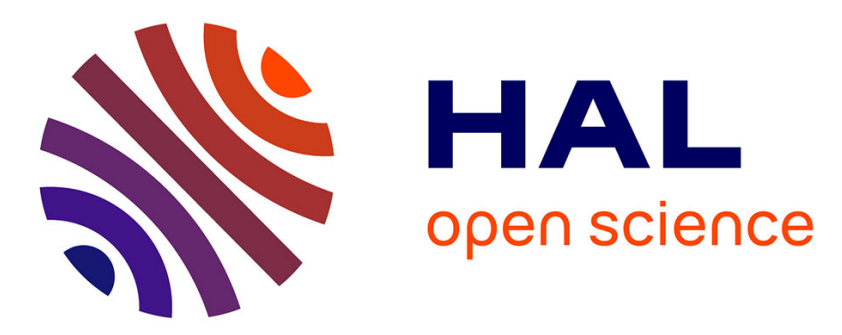

\title{
Napoleon, nostalgia and number plates: an analysis of the reactions to the Attali Commission's proposal to abolish the French department
}

\author{
Paul Stephenson
}

\section{- To cite this version:}

Paul Stephenson. Napoleon, nostalgia and number plates: an analysis of the reactions to the Attali Commission's proposal to abolish the French department. Journal of Contemporary European Studies, 2012, 20 (4), pp.477-495. 10.1080/14782804.2012.737664 . hal-01024676

HAL Id: hal-01024676

https://hal-sciencespo.archives-ouvertes.fr/hal-01024676

Submitted on 16 Jul 2014

HAL is a multi-disciplinary open access archive for the deposit and dissemination of scientific research documents, whether they are published or not. The documents may come from teaching and research institutions in France or abroad, or from public or private research centers.
L'archive ouverte pluridisciplinaire HAL, est destinée au dépôt et à la diffusion de documents scientifiques de niveau recherche, publiés ou non, émanant des établissements d'enseignement et de recherche français ou étrangers, des laboratoires publics ou privés. 
This article was downloaded by: [FNSP Fondation National des Sciences Politiques] On: 16 July 2014, At: 06:09

Publisher: Routledge

Informa Ltd Registered in England and Wales Registered Number: 1072954 Registered office: Mortimer House, 37-41 Mortimer Street, London W1T 3J H, UK

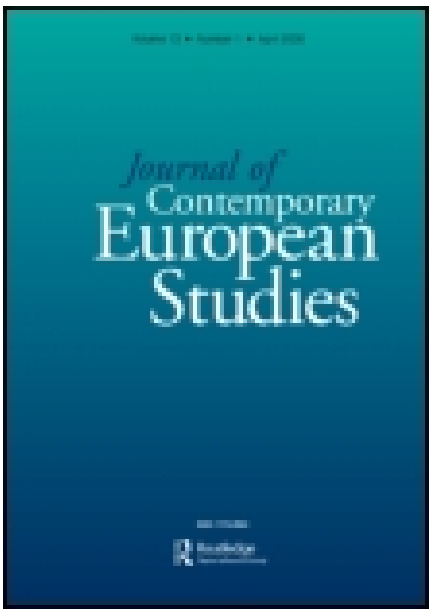

\title{
J ournal of Contemporary European Studies
}

Publication details, including instructions for authors and subscription information:

http:// www. tandfonline.com/loi/ cjea20

\section{Napoleon, Nostalgia and Number Plates: An Analysis of the Reactions to the Attali Commission's Proposal to Abolish the French Département}

\author{
Paul J. Stephenson ${ }^{\text {a }}$ \\ ${ }^{a}$ Maastricht University, The Netherlands \\ Published online: 07 Dec 2012.
}

To cite this article: Paul J. Stephenson (2012) Napoleon, Nostalgia and Number Plates: An Analysis of the Reactions to the Attali Commission's Proposal to Abolish the French Département, J ournal of Contemporary European Studies, 20:4, 477-495, DOI: 10.1080/ 14782804.2012.737664

To link to this article: http:// dx.doi.org/ 10.1080/ 14782804.2012.737664

\section{PLEASE SCROLL DOWN FOR ARTICLE}

\begin{abstract}
Taylor \& Francis makes every effort to ensure the accuracy of all the information (the "Content") contained in the publications on our platform. However, Taylor \& Francis, our agents, and our licensors make no representations or warranties whatsoever as to the accuracy, completeness, or suitability for any purpose of the Content. Any opinions and views expressed in this publication are the opinions and views of the authors, and are not the views of or endorsed by Taylor \& Francis. The accuracy of the Content should not be relied upon and should be independently verified with primary sources of information. Taylor and Francis shall not be liable for any losses, actions, claims, proceedings, demands, costs, expenses, damages, and other liabilities whatsoever or howsoever caused arising directly or indirectly in connection with, in relation to or arising out of the use of the Content.

This article may be used for research, teaching, and private study purposes. Any substantial or systematic reproduction, redistribution, reselling, loan, sub-licensing, systematic supply, or distribution in any form to anyone is expressly forbidden. Terms \& Conditions of access and use can be found at http://www.tandfonline.com/page/termsand-conditions
\end{abstract}




\title{
Napoleon, Nostalgia and Number Plates: An Analysis of the Reactions to the Attali Commission's Proposal to Abolish the French Département
}

\author{
PAUL J. STEPHENSON* \\ Maastricht University, The Netherlands
}

\begin{abstract}
Soon into his term as President, Nicolas Sarkozy commissioned Jacques Attali, former adviser to François Mitterrand, to investigate ways to 'free up' economic growth. Decision 260 of the report published in February 2008 recommended doing away with the French department completely. The report reignited a decades-long debate about streamlining the levels of France's public administration. Drawing on websites and internet blogs, including Attali's own, this article examines civil society reactions to the proposal, uncovering diverse and conflicting attitudes towards the department, while revealing it to be the most 'accessible' expression of the Republic, bound up with the self. In many senses, this artificial political construct, purposely created to bear no reference to history or belonging, has paradoxically become a significant carrier of French culture and territorial identity.
\end{abstract}

KEY WORDS: Nicolas Sarkozy, Attali Commission, decentralisation, sub-national politics, public administration, experts

\section{Introduction}

In December 2011, the French National Assembly modified the rules in place that formerly allowed a Département (referred to hereafter as 'department') to hold a referendum to enable its inhabitants to decide whether or not to become part of a different région (region). The Assembly of French Départements (ADF) ${ }^{1}$ called it an affront to democracy and the freedom of expression. A few months earlier, in March, a small Indian Ocean island (population 186,000) in the Mozambique Canal, called Mayotte, became the newest department (and at the same time, region) of France, following a referendum two years earlier in which 95.2 per cent voted in favour; the second most densely populated of France's now 101 departments, its official number is $976 .^{2}$

Yet three years before, in early 2008, it looked as if the departmental level would be abolished altogether. The idea was put forward by a mixed gathering of 'experts', assembled at the request of newly elected president Nicolas Sarkozy, with the aim of identifying ways

*Correspondence Address: Department of Politics, Faculty of Arts and Social Sciences, Maastricht University, PO Box 616, Grote Gracht 90-92, 6200 MD Maastricht, The Netherlands. Email: p.stephenson@ maastrichtuniversity.nl 
to stimulate growth (libérer la croissance). The proposal attracted extensive media coverage, even before the formal submission of the report, generating editorials and exchanges of opinion across civil society. It reignited a long-running debate about streamlining — or reducing the layers of - France's public administration, and laid bare the sensitivities of the population when attempting to tinker with the clearly demarcated territorial units of the French state. The controversy continued a year later, fuelled by the announcement that from 1 January 2009, number plates (plaques d'immatriculation) would no longer automatically indicate the code of the department in which the car was registered.

In his contribution to Vincent Wright's edited volume back in 1979, Conflict and Consensus in France, Howard Machin concluded that 'whilst there are doubts and ignorance about the régions, the identities of communes and Départements are known to all' (Wright, 1979, pp. 148-149). He asserted that, while there were no comparative criteria to determine whether the operations of the French system were 'better or worse, more or less efficient or democratic, than those of neighbouring States', it was clear that local institutions were adapting quickly to 'massive and rapid changes of population and demand for services', while acknowledging (and accepting) certain delays and difficulties of excessive centralisation (Wright, 1979, p. 149). Though dispersed across the French territory, the department may have been an essentially artificial, centralist imposition- the omnipresent eye of the State replacing the 'natural' provinces based on topography and landscape — but it had an identity. ${ }^{3}$ Why then attempt to abolish a well-established layer of administrative governance? How exactly is the department perceived today by politicians and civil society? The regionalisation process of the 1980s, and the concentration of powers in larger territorial units-England's nine regions, Germany's sixteen Länder, Spain's seventeen Comunidades Autónomas, France's twenty-two régions-raises questions about the continued worth of the department. Is it still deemed to be coping well with the demands of competing in a single market and global economy?

This article examines the arguments put forward by the Attali Commission in favour of its abolition, and then the reactions to the proposal—for and against—among civil society. Taking forward the decentralisation/regionalization debate, it seeks to reveal how the Attali Commission perceived France's economic situation vis-à-vis its neighbours, and why altering dispersed state structures was seen as conducive for the economy. It uncovers a wide spectrum of public opinion regarding the department. What were the issues shaping public opinion on the proposed abolition? What were the perceived implications for the State and the individual? Was it just about the perceived inefficiency of administrative governance?

The article exploits online blogs for qualitative research on French politics, to make an innovative contribution to the study of sub-national politics by honing in on debates regarding culture and identity. In order to gauge civil society opinion, the article considers French current affairs magazines as a valuable primary resource for capturing public opinion. The bulk of the data was gathered in the period late 2007-early 2008, but as is the nature of online media, many of the hundreds of 'contributions' - which together give an impression of the proposal's societal reception-remain retrievable today. Examining emotional attachment to, and alienation from, this territorial unit of the State, the article sorts and groups the opinions, to identify eight dominant narratives within the civil society debate.

The second section contextualises the debate by looking at the recent political background of regionalization, in order to provide a background into French territorial politics. The third section discusses the composition and role of the Attali Commission and 
the proposals generated. The fourth section discusses the methodology behind the empirical research and what the analysis of blogs can offer researchers in European studies and comparative politics in terms of qualitative methods. The fifth section interprets an array of opinions and exchanges logged on blogs to reveal how the French public was concerned largely, but not exclusively, by the implications of the proposed abolition for culture and identity.

\section{Situating the Département}

The process of decentralisation in Europe, coupled with regionalisation, has been addressed by scholars of comparative politics and regional studies in the last thirty years (Keating, 1983; Palard, 1993; Castles, 1999; De Vries, 2000; Warleigh, 2003; Ashford, 2006; Mathias, 2006; Loughlin, 2007; Wyn Jones \& Scully, 2010). French politics scholars have analysed the social, political and administrative history of decentralisation from Paris to the provinces (Schmidt, 1990, 1991; De Montricher, 1995; Loughlin \& Mazey, 1995; Thoenig, 2005; Cole, 2006, 2011; Bezes, 2010; Bezes \& Le Lidec, 2010; Pasquier, 2010). Transformations in administrative governance at the various levels has been studied with regards to local government (Négrier, 1999; Cole \& John, 2001), urban governance (Nicholls, 2005), Europeanisation (Mazey, 1994; Pasquier, 2005; Ladrech, 2008), policy networks (Cole \& John, 1995) and new public management (Cole \& Jones, 2005; Ongaro, 2010). Much of the focus has been on shifts in power distribution, and the concerns of French political elites. In the minority, perhaps, are those scholars who have examined the political sociology of the process of territorial change, bringing a cultural dimension to regional studies and looking at populations and collective identities, rather than elite concerns. This includes work on the cultural sociology of space (Richardson \& Olsen, 2003), the link between political institutions and identity (Boman \& Berg, 2007) and 'Europe' as a social process (Paasi, 2001). Gallagher and Smith (2010) have examined French national perspectives on culture and globalisation.

\section{The Département as Subject}

Scholarly analysis of the French department has its foundations in the seminal work of Howard Machin (1977) whose book The Prefect in French Public Administration examined the unique and powerful position — theoretically at least—of the French prefect in French local administration, at the very heart of formal, institutional politico-administrative structures. Machin placed the prefect in historical context and accounted for role adaptation to changing social, economic and political circumstances. This called into question the notion of the prefect (and department) as symbolising the 'Napoleonic ideal of unified, rationalized administration and the Marxist view of the State as unified instrument of oppression'; rather than showing the unity of the state machine, he revealed local public administration and its territorial structures to be 'incoherent' and 'irrational' by nature (Machin, 1977, p. 204).

Much contemporary scholarship today in European politics sees scholars using rational choice institutionalism to examine principal-agent relations, with regards to the study of EU agencies and in multi-level governance more broadly. Yet in the late 1970s Machin was examining such dynamics, identifying areas of relative autonomy with the political sub-national structure of the State. He also addressed relationships, attitudes and 
behaviour by using sociological institutionalism avant la lettre. Though weak individually vis-à-vis their political masters in Paris, collectively the prefects could assert real influence in determining their role and enjoying a certain independence:

If, in reality, the influence of many Prefects is limited, the myth of prefectoral authority still survives. It is an ingenious game, an elaborate bluff, a very convenient myth which the prefects have every reason to foster. As long as total reality is masked, as long as some people continue to speak of, believe in or simply attack prefectoral power, the corps can maintain its self-respect and pride. Paradoxically, criticising prefectoral pre-eminence, the parties of the opposition are the Prefects main ally in preserving the myth. (Machin, 1977, p. 206)

Three decades later, Le Galès (2008) traced the decentralisation process that has occurred in France since the early 1980s and acknowledged the 'departmental heritage versus the towns and regions'. French state attempts at centralisation up until the 1960sthe so-called 'domesticated Jacobinism' - aimed at modernising the French economy and society, but came up against pressures for increasing powers at the sub-national level (collectivités locales). Levels of administrative governance were seen to be engaged in competition, giving way to a dynamic of decentralisation to appease the countryside (les territoires), beginning with the failed referendum to create regions in 1969, but getting underway in earnest with the 1982 laws on decentralisation that carved France up into twenty-two Metropolitan (artificial) regions. Proposals to abolish the prefect and his department are nothing new, but the regionalisation movement gave new momentum to the campaign, effectively pitting large groups of elites within France's public administration head-to-head. In a nutshell, the last thirty years has seen an ongoing tug-of-war, one might say 'turf battle' — quite literally_between the maintenance of the 'inherited' system (commune, department) and the introduction of new governance structures (structures intercommunales in urban conurbations, and regions) (Le Galès, 2008, p. 451).

\section{Centralist Origins}

The departments were supposedly created by law on 4 March 1790 to replace the provinces. Their size was fixed, so that the prefect could go from main town to any point on horseback in a day (today's equivalent of five minutes in a TGV). As such, they can be understood as part of a process of 'de-territorialisation' to get rid of the Ancien Regime, but also as part of a more modern form of 're-territorialisation'. If in the eighteenth century the new jurisdictions were created in accordance with the needs of the central state representative en province, in the twenty-first century this relatively small geography is argued by many to be conducive for rural populations to access public services in the main urban centre, or prefecture- 'the spatial translation of the principle of equality'. In the department, the central state did not dilute its powers, merely dispersed them.

With the creation of the system of elected representatives for the General Council (Conseil Général) in 1833, the central state created new spaces for dialogue between Paris and local elites. While the provinces were judged to be counter to the homogeneity of the nation, the new carve-up (decoupage) was part of a new rational approach that broke with the aristocratic provincialism of the eighteenth century, promoting modernity and egalitarianism. In some areas it also marked a religious rupture, promoting the secular 
organisation of territory, such as in the Marne, where Châlons was chosen over sacred Reims as the prefecture. Similarly, the creation of the Rhône department was meant to weaken Lyon by cutting it off from its hinterland. The number of departments grew from the initial eighty-three, to 130 in 1810 with the annexing of the Republic and the empire's reach into Germany, the Netherlands, Italy and Spain, but then after the fall of the emperor in 1815 fell back to eighty-six. By 1922 there were ninety. Four outre-mers departments were created in 1946 (plus the fifteen Algerian departments until 1962). Six more resulted from the reorganisation of Paris in 1964 and the division of Corsica into two departments in 1976, bringing the total-with Mayotte-to today's 101 local administrative units. ${ }^{4}$

However, criticism of the department began more than a century ago. In 1884, the Chamber of Deputies already felt the department was not suitably adapted to the territory-its 'delineations' already obsolete and anti-democratic. It was seen to privilege rural cantons, leave cities under-represented and be unresponsive to development needs. In 1906, Clemenceau (prime minister 1906-1909, 1917-1920) referred to adapting territorial structures to better take into account economic and social change. In 1947, Michel Debré (later prime minister 1959-1962) proposed creating forty-seven mégaDépartements. President Giscard d'Estaing (1974-1981) asserted: 'one day we'll need to decide between the region and the department because you can't have two intermediary levels between the [central] State and the communes' (www.reformer.fr). ${ }^{5}$

\section{Multi-Level Territorial Administration Today}

Decentralisation began in earnest in 1982 under Prime Minister Pierre Mauroy (1981-1984) while Gaston Defferre was 'Minister of Interior and Decentralisation' (1981-1983), although President Mitterrand remained firmly opposed to the process. With the Law of 2 March 1982, the region became a 'local collectivity', bringing a fifth tier to French public administration: EU, state, region, department and commune (plus 15,000 structures for co-operation between communes). The departments were endowed with further competences in 1983 and 1985, and again in 1988 when they were given responsibility for the minimum wage (RMI). Acte II of 13 August 2004 brought a further transfer of competences and budget, notably in social and economic aid, management of roads, education and cultural heritage (patrimoine).

According to the 2009 census the average population of the ninety-six metropolitan departments was 650,685 - more than twenty times the number of a US county but twothirds of a UK county; their size varies and is arbitrarily determined. ${ }^{6}$ The stereotypical image is of a main town, a few medium-sized towns and then a large rural space. In a 1999 debate on the Voynet Law (25 June 1999) or formally-loi d'orientation pour l'aménagement et le développement durable du territoire - the department was seen as an excessive, archaic, conservative, undemocratic and anti-urban jurisdiction, compared with the modern trio: agglomération, région, Europe.

The regions took some time to get established-as Le Galès (2008, p. 461) asserts, they were weak at birth and with comparatively few resources - their budgets have since grown, and newly elected councillors have worked to increase their political stature. By putting into place 'European regional policies' and state-region contracts, the politics of the regions has disentangled itself from that of the departments. Nonetheless, many fail to see, or consciously choose to reject the region, dismissing its supposed geographical/ topographical logic, contesting the artificial border of the Pays de la Loire, Midi-Pyrénées, 
Centre, Provence-Alpes-Côte d'Azur, and protesting that more public sector posts have brought no obvious increase in transparency or effectiveness. Yet, if anything, the process of regionalisation and decentralisation has even reinforced the departments, by carving out new functions and encouraging contractual politics initiated by the State. They have had a greater adaptive capability than the regions, which have failed to take root politically or capture the collective imagination. In 2003, two referenda in Corsica and Guadeloupe/ Martinique proposing to replace the departments with a single territorial administrative entity were rejected.

\section{The Attali Commission}

\section{The Experts and Their Task}

In late August 2007, President Nicolas Sarkozy gave Jacques Attali, head of PlaNet Finance $^{7}$ and former special adviser (sherpa) to François Mitterrand, a month to reflect upon how to 'free up growth', and to make his first proposals so that they could be put into place immediately (see Attali, 2005). According to Stevens (1979, p. 79), Attali was 'the Socialist Party's economic expert'. He had been one of the drafters of the state-inspired proposals (110 propositions), drawn up in 1981 for President Mitterrand, and which largely influenced policies enacted during his two terms (1981-1988 and 1988-1995). Notably, the fifty-fourth proposal on decentralisation was later enacted, leading to the 1982-1983 laws on state decentralisation, while the fifty-sixth proposal called for state support of regional identities. Some twenty-two metropolitan regions (of twenty-seven) were set up in March 1982, with the first direct elections for regional representatives in March 1986.

The idea of the 2007 Commission was to find ideas to 'take the brakes off' the economy, or rather, to dismantle those elements stifling the French economy. The Commission was to make a diagnosis of the symptoms (handicaps), and make concrete proposals to be taken up in legislation for modernising the economy, being prepared by the then minister of economy and finance, Christine Lagarde, now director of the International Monetary Fund (IMF) since July 2011. To the forty-three members of the Commission who gathered at the Elysée, Sarkozy claimed the country needed an 'intensive modernity treatment' (cure), since France had 'lost too much time' and needed to 'increase growth to get back to (retrouver) full employment'. He added that 'this is not an exercise de style ... it is not just another report; whatever you put forward, we will do.' (L'Express, 30 August 2007) And yet we see they did not. The Commission met three times a week with the help of fifteen full-time assistants. The aim was to produce a short report-one that would inform government reports and which could be applied in all policy areas: purchasing power; employment; and firms.

The Commission was made up of a diverse range of people: psychiatrist Boris Cyrulnik; the head of Areva, the French nuclear energy group, Anne Lauvergron; head of Orange France, Jean-Noel Tronc; former secretary general of French Democratic Confederation of Labour (CFDT), ${ }^{8}$ Jean Kaspar; and the writer Erik Orsenna. There were also foreign personalities: the CEO of Nestlé, Peter Brabeck-Letmathe; former Spanish minister for foreign affairs, Ana de Palacio; and British historian, Theodore Zeldin. Regarding the participation of a psychiatrist in the group, Attali confirmed that one of the principal constraints upon growth was that France is not happy (la France n'est pas gaie) and that they needed somebody to determine why. ${ }^{9}$ Attali referred to an exceptional mood and 
mindset among those gathered (état d'esprit qui règne autour de la table) (L'Express, 25 October 2007). Members were not paid, and only the travel costs of the foreign participants were reimbursed. The French state would get the rights of authorship to any publications resulting from the work, and the exercise would cost the State nothing-in fact would produce revenues, or have a 'positive budgetary effect' (L'Express, 25 October 2007). Yet, it is uncertain how these individuals were chosen, certainly raising questions about what constitutes expertise.

\section{The Key 'Decisions'}

On 23 January 2008 the Commission turned in its 245-page Report on How to Stimulate Growth in France (Rapport de la Commission pour la libération de la croissance française). It contained four parts: participating fully in global growth; safe and mobile actors; new governance for growth; and successfully freeing up growth. ${ }^{10}$ Each part was made up of either 'ambitions' or 'objectives', and each part followed by a 'key decision', which was in fact not a decision at all, since the group had no legal powers-but a recommendation. In total there were 316 'decisions', almost three times as many proposals as made in 1981. It was calculated that the measures would bring about a growth of 0.8 per cent GDP (L'Express, 15 October 2008).

A marked feature of the report was its language. It alluded to 'growth that is already there but enchained'; implying it simply needed to be released. It assumed a simple causal linkage between negative integration-removing barriers-and positive growth 'Decisions' included: revising the definition of redundancy (licenciement économique) to make it more attractive for firms to take on staff if they can also fire them more easily; reducing agricultural subsidies; encouraging wider wholesale distribution (grande distribution) by abolishing laws (Royer, Raffarin Galland); ${ }^{11}$ supporting small businesses by creating 2000 SMEs of 500 employees each and establishing a single independent authority for competition; building 500,000 new homes a year and ten new sustainable (ultra-écolo) 'towns of the future' at 50,000 inhabitants each; and within five years, constructing no less than 3 million quality homes to help those on lower incomes pay affordable rents.

In L'Express on-line chat on 25 October 2007, Attali foresaw a social and political crisis, underlining the need for greater social mobility and of steps to reduce inequality; France supposedly lacked a national dream like the one Germany had had with reunification. There was, he argued, a massive need to simplify administrative rules and procedures by looking abroad and using new technologies. The uprooting (délocalisation) of firms was a 'tragedy', something that would need to be offset by more immigration. Incentives for early retirement ( préretraite) were to be actively discouraged; Attali felt that, not only was it a 'considerable waste', but the State was ageist by not making more use of the elderly. The Commission proposed removing barriers to access in regulated professions and ending the monopoly of taxis, chemists and lawyers (notaires and avoués).

Attali clearly redefined the criteria that constitute 'growth', traditionally based on GDP calculations and paid no consideration to the societal well-being. He said, "we must speak in terms of THE growths and not THE growth. By that I mean growth in environment and social justice is essential.' He spoke of growth beyond immediate profit, making explicit reference to salaries, investment, share dividends, but also other revenues for societal actors. Growth was not the problem but 'all production is creative destruction'. Along these lines exploitation can only be avoided if the conditions of organised production are 
legitimate; democracy's role was to create such positive conditions, but remained, nonetheless, a utopian ideal. Such concerns for social justice and equality might seem at odds with the pursuit of economic growth but may be explained by Attali's recently published biography of Ghandi.

\section{Decision 260}

The third part of Chapter 3 of the six-chapter report was entitled 'Simplifying the decentralisation process for increased efficiency' (Clarifier la Décentralisation pour en Accroittre l'efficacité). It contained four-and-a-half pages (pp. 195-199) of discussion around France's 36,000 communes, 100 departments, twenty-six regions, 18,000 inter-communal structures and 2,580 public bodies for inter-communal co-operation (Etablissements publics de coopération intercommunale (EPCI)). With over 550,000 elected posts at various levels, the report advocated that decentralisation had 'paralysed' growth, bringing with it massive additional costs. The second act of decentralisation from the Law of 28 March 2003, and subsequent 'organic laws' of 2003/2004, had not brought the restructuring that the French economy needed. The Attali Commission felt reform should be double-pronged, dividing up the competences more clearly among the administrative layers and giving each its own financial resources.

The most controversial of the twenty fundamental 'decisions' - no decisions were actually taken, these were actually merely recommendations for Sarkozy_was 'to reinforce the regions and the inter-communal structures' by abolishing the department. Other decisions included: strengthening the regions (258), transforming certain inter-communal structures into urban agglomérations by giving them legal recognition (259); and making the departmental level disappear within ten years (260). Members of the Commission considered this administrative level (échelon) to be out-of-date (dépassé), irregular (hétéroclite) and even destructive (iconoclaste). It felt competences of the General Councils should be devolved (up!) to the regions and (down) to other inter-communal structures. Moreover, it felt that the 36,000 communes should be abolished to create 6,000-7,000 'supercommunes', to be elected by universal suffrage. The town mayors (maires des communes) would still exist but become the equivalent of the mayor of an arrondissement as in Paris, Lyon, Marseille; this in itself would lead to a half or 1 per cent $(0.5-1$ per cent) reduction in compulsory tax; and the departmental offices (hôtels de department) could be sold off.

\section{Methodology}

\section{Using Online Opinion for Social Research}

Since 1999 blogs have steadily become a significant feature of online culture, heralded as the 'new guardians of democracy, a revolutionary form of bottom-up news production and a new way of constructing self and doing community in late-modern times' (Hookway, 2008, p. 91). Blogs, on-line posts, live chats and personal websites are new information sources for qualitative researchers, providing easy access to data generated by virtual communities, the membership of which is often not monitored or vetted. Traditional research methods, such as interviews and surveys can now, to a limited extent, be transferred to the online context; what one cannot ascertain in depth with a single participant, one can arguably compensate for in breadth by gauging a larger number. That said, while the internet has been used in social 
sciences quite extensively for quantitative style surveys, there has been a slower response by qualitative researchers to taking up the opportunities afforded (Hookway, 2008, p. 92).

As Hookway (2008, p. 91) asserts, alluding to Putnam (2000), much of the debate on such communities has looked to cyberspace as 'an answer to the (post)modern problem of "bowling alone", while, after Baudrillard (1983) 'the discussion of online identity production has addressed the question of how the virtual world's "culture of simulation" facilitates a type of postmodern realization of the "decentred" and "disembodied" self'. This explicit reference to decentring would seem most apt for the case of the departmental level. Contemporary journalism has become increasingly participatory, serving as a collective diary of record of opinion and sentiment, given the opportunity to comment on stories beneath them, and to do so with relative immediacy. As such, online newspapers and magazines encourage two-way communication between writers and readers, but also help forge communities of readers who themselves engage in dialogue. Website blogs 'collect' diverse viewpoints on shared experiences or issues, thus serving as a collective databank (Gill, 2004). Often with little or no editorial oversight, they themselves act as informal editorials on the official story, as a watchdog on the newspaper, checking facts and monitoring the quality of reporting.

The advantage of gauging online opinion is that it is low-cost, instantaneous and can be scanned quickly to build up a general sense of opinion. Moreover, blogs are naturalistic in their textual form and do away with some of the artificial constraints inherent in any fieldwork exercise. In addition, the online 'environment' is anonymous meaning that bloggers may be less conscious in what they write than if being recorded or filling in a form. Online venues engage populations spanning large geographies, sometimes socially removed from the researcher. Because blogs are archived, the researcher is able to examine social comment over time and trace variations in activity-frequency, density, shifts in focus. Some might argue that they have a socially transformative capacity or even reinvigorate the public sphere (see Hookway, 2008, pp. 93-94).

\section{Data Collection}

Besides referring to the Attali Commission's report, the proceeding analysis draws largely on French media sources (Le Monde, L'Express, Le Point), including Attali's own 'blog' on the L'Express website ('Conversations avec Jacques Attali')—as well as opinions on popular news and current affairs websites including www.20minutes.fr, and www.cafe-geo.net. In particular, the article analyses a survey conducted by the Benchmark Group on behalf of L'Internaute Magazine, France's most popular internet magazine-a consumer magazine of information, culture, travel and hobbies, with interviews and opinion polls. It had 8.7 million readers/visitors in May $2007^{12}$ up from 4.8 million in December 2005 when 128 million pages visited each month and 1.5 million people subscribed or signed up (abonnés). An opinion poll launched in November 2007 and entitled 'For or against doing away with the departments?', Intern@ute Magazine (www.linternaute.com) asked three questions: Why are you in favour of keeping or doing away with the departments? Would such a step make the management of the French territory more efficient? Do you think such a step might have repercussions for your daily life? ${ }^{13}$

\section{Reactions to the Proposal}

There were 275 responses to the L'Internaute Magazine survey expressed over a three month period between 12 November 2007 and 7 February 2008, with three clear peaks in 
activity: August-October 2007, between commissioning the report and one month prior to the deadline; January 2008, when the final report was submitted; and May 2008 when news broke about the removal of departmental numbers from new car number plates. In most cases the date and even time of the 'communication' was given, as well as a pseudonym or user name, though in some cases commentators gave their full name and professional affiliation. The site registered 156 people in favour of the abolition, 109 against and ten undecided. However, no qualitative analysis of the often lengthy, detailed responses was made by the site. In addition, general opinions on the issue were expressed on other sites: 20 on www.rue89.com, 15 on www.letelgramme.com, 55 on www.lanouvellerepublique.fr and 78 on www.agoravox.fr. These ranged from a couple of words to several lengthy paragraphs of reminiscence or hypothesising. The remainder of this section groups the responses into eight main issues, based on the total of over 430 expressions of opinion. ${ }^{14}$

\section{The Historical Legacy of Administrative Culture}

Though part and parcel of French political culture, some felt the department to be outof-date and advocated sweeping away the dust and cobwebs-'un bon coup de balai sur notre administration poussièreuse' - of an ever complex multi-layer administration (Cambronne, 14 January 2008 at 12.01 pm, www.agoravox.fr). Culinary references were made to French pâtisserie and Italian pasta - to public administration as a 'territorial lasagne'. Even the writer Erik Orsenna, a member of the Commission, felt the departmental layer was an obstacle to economic development:

Yes to getting rid of this administrative millefeuille ${ }^{15}$ that suffocates economic development. I have seen how territories are organised in many places. But never have I seen so many administrative layers as in France. They say it sews things together but it also causes blockages, at every level, from the town to the State. (lerma, 14 January 2008 at 10.09am, www.agoravox.fr)

Many respondents saw the department as the embodiment of the Republic, evoking and symbolising both the revolutionary spirit and Napoleon, who sought to control all French men-it was 'a historic reality' or 'a creation of the Revolution', and that to try to abolish it was unnecessary interference by a useless political elite:

Kill the departments? Never. The 29 will always be the 29. Imagine a child in a few years time asking, 'Where were you born?' 'Er, I don't really know, somewhere in Europe.' My parents often talk of Finistère, but they are old and Pen ar Bed is no longer on the map, I'm not sure ... Let's stop messing around. Instead, give our dear Enarques [graduates of the Ecole Nationale d'Administration ] shovels and pick axes so they can make themselves useful. (Cariou, 21 January 2008, www.letelegramme.com)

At the same time, some acknowledged their arbitrary nature, established by Jacobin technocrats for better control but with no geographical rationale; they were a class construct for the profit of the centre. Some recognised this tradition but were sceptical about strong regional power, defending the commune-department duo as defending Republican values, notably equality; others saw the future merit in the region: 
For a long time France (and by that I mean our politicians) has had this odd relationship with its land. Always some rather absurd technocratic approach ... The region is unquestionably a territorial scale that makes more sense and that will be more useful in the future. (touchpasamondepartement.fr, 24 March 2008 at 9.55am, www.lanouvellerepublique.fr)

\section{Distance in State-Citizen Relations}

The department was seen by many to guarantee contact between citizen and state; and where the individual was close to the prefectoral level it was distant from the region; what people needed was less state (department) not more (region). They were an 'asset', the State's privileged contact with the citizen. As such they were seen as crucially important for collective memory, especially in the countryside. French history was at stake, since subnational administrations had developed a local history. To destroy this history would be to consider the departments as they once did the provinces-history repeats itself, rapidly erasing collective memory:

Doing away with the department would be a massive mistake, a step backwards to over 200 years ago. To start creating regions would distance the citizen from societal life. It would push us back towards some idealised past that never existed in the first place and that divides people. Having departments is a way to bring the State closer to the citizen. That's why we should decentralise instead of regionalise. The citizen doesn't want less state, but to be able to take a bigger role in the life of the State. (Richard Patrosso, 14 January 2008 at 2.55pm, www.agoravox.fr)

Citizens need to attach to a level where they have the impression of being able to control the decision-making powers - the administrable and psychological success of the department (Michel Collardelle, director of the Museum of European and Mediterranean Civilisations, La Croix, 28 January 2008). Indeed, the irony is that many respondents appropriated the region with the centre, when it is actually a vehicle for devolved powers, and saw the departments-historically a tool of the central state-as more decentralised, something which arguably has to do with geographical size; the department is seen as an instrument for ensuring 'closeness' ( proximité), keeping in touch with what is happening with your ear to the ground (des antennes locales) and as 'batons for the regions' (des relais des régions):

Deep down I am somewhat in favour of seriously reforming our territorial politics. That doesn't mean though that I'd go as far as getting rid of the departments, just those areas where there's duplication with existing powers at the regional level. (fergus, 14 January 2008 at 10.59am, www.agoravox.fr)

\section{Education, Childhood and Summer Holidays}

Perhaps the most easily evoked reference was to the two-digit departmental numbers learnt at school. While the region is (only) known by its logo, the number has taken on a symbolic force. Indeed, the proposal to remove it from vehicle number plates caused strong emotion. Matching the number with the department was seen as a pleasurable educational game, to be played with younger generations and an aid to learning geography. 
As such it had a role to play in forging inter-generational relations. When away, it was a way of conversing about where you are from and what you are doing there; it left open the possibility of being able to talk about home. It was also bound up with childhood and summer holidays_-'Remove the folklore and what's left of our holiday fun?':

For me the departments are an unforgettable page of my childhood. They were July and the month when we went on holidays, my parents busy the whole evening before packing everything six people needed for three weeks, into the old iron trunk. In the morning they'd wake us for breakfast. We were made to swallow our Nautamine or Dramamine pill to prevent car sickness. Once the trunk was firmly tied to the roof rack, my brothers, my sister and me climbed into the back and waited to set off on our long journey, like each year, that would take us from our home in Malakoff (92) to the confines of Limousin and Poitou and as far as Vienne (86) and Haute Vienne (87). (Thorgal 46, IT technician, Cahors, 4 Februaury 2008 at 7.28am, www.rue89.com)

\section{Identity, 'We-ness' and the Other}

There was evidence that the department has taken on its own an economic value in terms of retail goods and is a powerful brand for merchandising. In street language the SeineSaint-Denis had become the '9-3'. The brand of clothing '64' designating Pyrénées Atlantiques was a common sign of association among the Basques. Abroad the 971 for Guadeloupe appeared on T-shirts. Consciously or not brandishing your departmental number had become a form of attachment to the Republic. In fact, online boutiques began selling departmental stickers, such as www.jaimemondepartement.com [I like my department dot com] where one could buy a range of goods including five car or window stickers for eight Euros:

And just look at what is happening in Seine Saint-Denis where young people no longer say that they live in the 93 [quatre-vingt-treize] but in the nine-three. It's an extraordinary phenomenon. Not feeling recognised by society, they have made their own identity based around their department in order to assert themselves as individuals ... We have added digits to identify phone numbers more easily and from the first number, be it a 4 or a 6 , can identify to which geographical area it belongs.

Departmental numbers were central to youth culture in certain areas of Paris and the Dom-Tom (overseas departments and territories), even an important marker of identity for disaffected youth. It is slightly ironic then that a Commission with economic growth as its concern failed to recognise the economic value of the department as a by-product of administrative governance, and something that could be exploited through tourism. To remove the numbers would be an attack on identity, rendering people anonymous:

To get rid of the departmental numbers would be to become anonymous and lose your identity, roots and origin. As far as I am concerned, Europe must not lead to anonymity. Yes, ok, there's a rationale behind it, and ok, there may be a problem 
with the current system, but why get rid of what is a symbolic means of identifying yourself? (10 January 2008, 21.35)

\section{Cars/Security/Anti-Paris/l'étranger}

From many respondents, there was a detectable antipathy towards the capital. For those living outside the big urban centres en province, the departmental number was itself an act of resistance against Parisian arrogance. The website www.touchepasamondepartement.fr was set up to encourage people to object, while selling car window stickers of the Hexagon-blue, with the department number and a smile. Many respondents presented narratives about being able to spot 'foreign' cars and then be on their guard, apprehensive that these visitors would not know the road. Did the political elites not see what value the numbers on registration plates served in terms of reducing accidents?

Other than educational value of the departmental numbers for teaching geography, there is one argument that has hardly been mentioned and which is crucial as far as I can see: security. Let me explain: when I'm in my department and I see a car in front of me that 'looks risky' on the road (qui a l'allure hasardeuse), my reflex is to look to see the number plate. If it is a 'foreigner' I pay extra special attention and expect him to manoeuvre badly ... which is often the case, but at least I am able to anticipate it. And another thing, I am able to show more consideration and understanding to a driver who is lost, when need be sending him off in the right direction. I appreciate the mutual understanding when not driving on my own patch. Our technocrats who bang on about road safety, have they really thought these things trough properly? (azéen, 15 January 2008 at 8.54am, www.lanouvellerepublique.fr)

That said, even if the number plates were made anonymous, it would still be possible to recognise bad driving; this measure would not make drivers any better:

I guess it might be difficult to identify Parisians behind the wheel but rest assured, the numbers might change, but people's behaviour stays the same. (pas d'accord, 11 January 2008 at $10.20 \mathrm{am}$, www.lanouvellerepublique.fr)

What would the Parisii [Parisian tribe] think if we erased their departmental island from the map? No more 75. Oh what a shame! Just wait and see what's next. Let's maybe dream of a new post code? Paris: 00000, Quimper: 00000, Limoges: 00000. (Cariou, 24 January 2008, www.letelegramme.com)

To the contrary, one blogger recognised the value of the departmental numbers because the quality of roads differed so much outside urban centres, often being full of holes; one needed departmental signs to keep the driver awake and forewarned:

If we get rid of the departments there will be too many drivers falling asleep at the wheel at night. There's nothing better to jolt you awake when driving on a brand new departmental road that's well signposted with super white stripes marked out and perfect surfacing than to suddenly find yourself zigzagging like Roger Rabbit in Toonville on a dodgy road, full of potholes and unable to see a thing until you pass a 
sign that reads: 'Welcome to the department of Côtes-d'Armor en Bretagne. (numerosix, prisoner in the global village, 4 February 2008 at 8.31am)

Others were less emotional, more pragmatic, recognising that numbers permeated so much of daily life, from postal codes to birth dates, taxes, diplomas, and that cars were not places in which one actually lived. What did it matter if they disappeared?

The departments are all about the post codes! And that's enough! With cars it was cool! But if things need to change so be it, let's not get emotional. The world is a big place, there's no point getting attached to a few numbers because there are numbers all around. Departmental numbers are linked to where we live, our home, birth place, work, school ... they appear on all formal document, identity papers, tax forms, diplomas, contracts ... we don't live in our cars!! (HB41, 28 May 2008 at 5.29pm, www.lanouvellerepublique.fr)

\section{Mediaevalism/Modernity and Rurality/Urbanism}

Many perceived the link to play in rural affairs and the 'roots' in old Gaul. One respondent wrote of how as a student he shared his room with a student from Chartres who was studying territorial divisions in the French Middle Ages, a subject called 'historical geography'. He helped him learn the names of the territories, fiefs, marches, bishoprics:

The one thing I learnt was that maps are not fixed. Hold them up to the light... do many lines make up a wrinkled face? Which Caravaggio is the most beautiful, the old Saint Jerome draped in purple or the young and sensual Saint John-Baptiste in sheep's skin? (plinaky, 19 January 2008, www.letelegramme.com)

From hamlets to villages, villages to towns, towns to cantons, cantons to departments, departments to regions, and then our beautiful provinces and the countryside, all that is our cultural heritage.

Others criticised such a viewpoint; and those who dreamt of the Middle Ages, with Sarkozy as king doing away with Republican departments to go back to feudal times. Noteworthy is that the musician Brassens was mentioned by many respondents, symbolic of a romanticised vision of France:

Far from adopting some Parisian or arrogant attitude, our goal is not to campaign for rural values (de valoriser «l'esprit de clocher») but to enable you to let the world know where your vehicle comes from. By no means are we going to defend a thesis on the subject, for as Brassens sang ... we are all 'happy fools born some place or other' (des imbéciles heureux qui sommes nés quelques part) ... but let's carry our two little numbers with us as we go about our business.

The departments were seen by many to 'come into their own' in the countryside. In towns people were even ignorant of them or saw them as irrelevant, with no raison d'être, just two 'existential' competences_-social aid and roads, hence two Frances: the department as backward rural life, social aid and a failure to modernise; on other hand regions and 
inter-communal structures as urban, modern and carriers of economic development. The departments were seen to over-represent the countryside at the expense of the urban population. Yet some recognised their role as mediator, arguing that when the State launches an action plan to tackle the suburbs, it looks to the department to manage it; as such, it could not ask a region to deal with problems in Seine Saint-Denis or Val-de-Marne.

\section{Germany, European Union and Globalisation}

There was a consciousness among some that French politicians were trying to imitate Germany, equating the department with the Kreis, even though there are three times as many (smaller) Landkreise or rural sub-divisions (295), in addition to 107 urban Stadtkreise. Moreover, they felt and the regions were too numerous and should be reduced in size to be able to compete globally. At the same time there was an acceptance that the French liked its layered administration even if it was harmful:

Germany has its Länder which have considerable autonomy in many policy areas (education, environment, social policy, culture, justice, police and I don't know what else) and all that works very well. But in France, we like our administrative layers, they preserve the status quo, it's like onions, except that they make you cry ... tears of laughter. (Jason, 14 January 2008 at 1.28pm, www.agoravox.fr)

With the prospect of globalisation, the department was felt to be a rampart defending the most vulnerable (on the minimum wage), meaning that any call to scrap them was seen as a cynical gesture in the name of commerce: 'To get rid of the departments is to get rid of France itself — some kind of repulsive marketing move.' Another blogger called it a global plot to reduce everything to the fewest numbers possible, to 'deny the human spirit':

Little by little I get the impression we are losing what identity we have left. The Communes are becoming communities. The sub-prefectures no longer have a place. The departments are becoming regions. France is becoming Europe. Not long until globalisation. (Jacqueline, 11 January 2008 at 1.17am, www.lanouvellerepublique.fr)

Get rid of the nations, regions, languages, differences, traditions. A single wine, a single cheese, a single religion, a single police, a single Führer. Such stupid and childish ideas that those promoting globalisation want to force upon us: to turn man into nothing but a digestive tube with genitals. To be involved at a local level, to be able to decide, to take responsibility for oneself, to be creative: these are the root of happiness and the very reasons for living. (dup, 14 January 2008 at 4pm, www.agora.vox)

One respondent suggested it would be better to getting rid of the Rue Nationale and all its chain stores, franchises, branches, in order to preserve the territorial identity of independent shops and businesses (fiojopaul, 12 January 2008 at 11.13am, www.lanouvellerepublique.fr). European integration had worn thin with some seeing 'Europe' as a threat to national identity. Moreover, the Euro had led to price hikes and a reduction in purchasing power; seeing a departmental number plate was, if anything, reassuring. Brussels was blamed as being behind the 'attack' on number plates: 
Since the Euro, so much has changed in France. Prices have gone up, purchasing power has fallen, and now they are getting rid of car number plates. Whatever next? I enjoy spotting a '37' when I'm abroad or just in the '13'. Let's stop taking people for fools .... or soon we'll all be called Europeans and no longer as French. (colombane, 12 January 2008 at 2.46pm, www.lanouvellerepublique.fr)

Moreover, how could France really hope to compete in the face of globalisation? Why not go further and suppress all sub-national levels of administration, in fact why not even the nation itself; if we were going to act out of economic interest then best to annex France to make it part of India.

Just think how it will mean the end of party bosses, local country squires, village tyrants, ultra-powerful petty bureaucrats who call the shots. Let's get rid of the cantons, communes, assemblies of old codgers drivelling on in useless meeting rooms with their open secrets and gossip. In fact, let's do even better and scrap France. For economic reasons, let's just annex it to Bombay, that wouldn't be so bad in fifteen or twenty years' time. NOT (Jason, 14 January 2008 at 1.28pm, www.agoravox.fr)

\section{Democracy/Legitimacy}

Finally, and perhaps unsurprisingly, some respondents expressed concerns that Attali and his Commission had not been elected; he was trying to run his own republic and using the EU as a means to his end:

The departments are the Republic. Attali (PS) is making use of European directives that aim to do away with the communes, departments and states that actually benefit communes together, and instead wants prefects for regions and a president of Europe. ELECTED BYWHOM? LONG LIVE THE 13, we must hold on to our dear departments. (Pascal, 27 January 2008 at 2.09pm, www.lanouvellerepublique.fr)

\section{Conclusion}

The article has revealed the sensitivities at the political heart of administrative governance, and the issues at stake in the debate over whether to reduce the levels of French public administration. Many saw the proposed abolition of the department as an attack on local cultural identity and even the Republic, the department being an inherent part of France's political culture, somewhere that a professional rite of passage occurs. Others felt it a sensible measure to ensure greater effectiveness and reduce costs. Between uncertain, political mistrust, the challenges of globalisation, and the proliferation and fragmentation of administrations at the level of the communes, the department is clearly for many citizens a familiar and stable structure on a human scale, one that guarantees social welfare. Paradoxically, many overlook the fact that the department was originally an artificial, political construction, but equate it instead with the decentralised state, and wrongly identify the larger region as part of a tendency to centralise, when it is in fact the contrary.

The analysis has shown how opinions are divided across France, revealing tensions between urban/rural, Paris/province, modern/Medieval, local/Europe and so on. In striving to compete economically, the department is undergoing its own existential crisis, as 
political elites look to France's immediate neighbours in a seemingly desperate attempt to identify the optimal size for its territorial units and structures that will 'free' growth. To some the debate may appear as window dressing, as merely tinkering with existing structures, rather than drawing up progressive economic and industrial policies, as if old wine tastes better in new bottles. In short, the department is a signifier of many things, defining and delineating the space and place in which the French population lives. The debate will reappear, igniting passions then falling back again into oblivion.

\section{Notes}

${ }^{1}$ Assemblée des départements de France. Available online at: www.departement.org/content/lassemblee-des-departements-de-france (accessed 30 August 2012).

2 Becoming an overseas department means adopting the same legal and social system as used in the rest of France, that is, abandoning some customary laws, adopting the standard French civil code and reforming the judiciary, educational, social and fiscal systems, all over a period of about twenty years.

3 Just three years after his study, with the laws of decentralisation the prefect's power as head of the department was usurped by the president of the general council, currently chief executive.

${ }^{4}$ NUTS 3, Nomenclature of Territorial Units for Statistics.

5 Bruno Rémond at: www.reformer.fr: 'Le site qui va reformer la république' (accessed 21 January 2008). See also Rémond (1998).

6 www.insee.fr: France's National Institute of Statistics and Economic Studies is a Directorate General of the Ministry of the Economy, Finance, and Industry (accessed 12 August 2012).

7 An international non-profit organisation that aims to alleviate poverty by contributing to the development of the microfinance sector. PlaNet Finance was founded by Jacques Attali on 13 October 1998 under the French legal status 'Loi 1901' (not-for-profit organisation). Available online at: www.planetfinancegroup.org/ (accessed 7 September 2012).

8 The Confédération française démocratique du travail (CFDT) is the largest five major French confederations of trade unions by number of members $(875,000)$ but second to the Confédération générale du travail (CGT) in voting results for representative bodies.

9 La France qui tombe and other literature, plus an IKEA advert satirising this doom-mongering.

${ }^{10}$ Participer pleinement à la croissance mondiale; des acteurs mobiles et sécurisés; une nouvelle gouvernance au service de la croissance; réussir la libération de la croissance

11 Since January 1st 2005, CEPREMAP is the CEntre Pour la Recherche EconoMique et ses APplications (Centre for Economic Research and its Applications). It's placed under the aegis of the Ministry of Research. Its mission is to provide an interface between economic research and public administration. Available online at: http://www.cepremap.ens.fr/version/ceprem/index_en.php (accessed 7 November 2012).

12 Source: Nielsen-NetRatings.

13 Pourquoi êtes-vous pour la suppression des départements ou au contraire leur maintien? Cette mesure rendrait-elle le fonctionnement des collectivités territoriales plus ou moins efficace? Pensez-vous que cette mesure pourrait avoir des répercussions sur votre vie quotidienne?

14 All entries/contributions have been translated from French by the author.

15 A millefeuille is made of many thin layers of stacked pastry-literally, 'a thousand leaves or sheets'.

\section{References}

Ashford, D. (2006) Territorial politics and equality: decentralization in the modern state, Political Studies, 27(1), pp. $71-83$.

Attali, J. (2005) C'était François Mitterrand (Paris: Fayard).

Baudrillard, J. (1983) Simulations (New York: Semiotext(e)).

Bezes, P. (2010) Path-dependent and path-breaking changes in the French administrative tradition: the weight of legacy explanations, in: M. Painter \& B. G. Peters (Eds) Tradition and Public Administration, pp. 158-173 (Basingstoke: Palgrave Macmillan). 
Bezes, P. \& Le Lidec, P. (2010) L'hybridation du modèle territorial français: la réorganisation de l'administration territoriale de l'Etat et la Révision générale des politiques publiques, Revue française d'administration publique, 132(4), pp. 919-942.

Boman, J. \& Berg, E. (2007) Identity and institutions shaping cross-border co-operation at the margins of the European Union, Regional and Federal Studies, 17(2), pp. 195-215.

Castles, F. (1999) Decentralization and the post-war political economy, European Journal of Political Research, $36(1)$, pp. $27-53$.

Cole, A. (2006) Decentralization in France: central steering, capacity building and identity construction, French Politics, 4(1), pp. 31-57.

Cole, A. (2011) France: between centralization and fragmentation, in: J. Loughlin, F. Hendriks \& A. Lindström (Eds) The Oxford Handbook of Local and Regional Democracy in Europe, pp. 307-330 (Oxford: Oxford University Press).

Cole, A. \& John, P. (1995) Local and policy networks in France and Britain: policy co-ordination in fragmented political sub-systems, West European Politics, 18(4), pp. 89-109.

Cole, A. \& John, P. (2001) Local Governance in England and France (London: Routledge).

Cole, A. \& Jones, G. (2005) Reshaping the State: administrative reform and the new public management in France, Governance, 18(4), pp. 567-588.

De Montricher, N. (1995) Decentralization in France, Governance, 8(3), pp. 405-418.

De Vries, M. (2000) The rise and fall of decentralization: a comparative analysis of arguments and practices in European countries, European Journal of Political Research, 38(2), pp. 193-204.

Gallagher, M. \& Smith, D. (2010) Empire and culture now: Francophone perspectives on globalization, Modern \& Contemporary France, 18(2), pp. 147-155.

Gill, K. (2004) How Can We Measure the Influence of the Blogosphere? Department of Communication, University of Washington (accessed February 2012).

Hookway, N. (2008) 'Entering the blogosphere': some strategies for using blogs in social research, Qualitative Research, 8(1), pp. 91-113.

Keating, M. (1983) Decentralization in Mitterrand's France, Public Administration, 61(3), pp. 237-251.

Ladrech, R. (2008) Europeanization and domestic politics and institutions: the case of France, Journal of Common Market Studies, 32(1), pp. 69-88.

Le Galès, P. (2008) La décentralisation de la Vème République: héritage Départemental versus villes et régions, Modern \& Contemporary France, 16(4), pp. 451-467.

Loughlin, J. (2007) Reconfiguring the State: trends in territorial governance in European States, Regional \& Federal Studies, 17(4), pp. 385-403.

Loughlin, J. \& Mazey, S. (Eds) (1995) The End of the French Unitary State? Ten Years of Regionalization in France (1982-1992) (London: Routledge).

Machin, H. (1977) The Prefect in French Public Administration (London: Croom Helm).

Mathias, J. (2006) Regions and regional politics in Europe, in: R. Sakwa \& A. Stevens (Eds) Contemporary Europe, pp. 213-232 (Basingstoke: Palgrave Macmillan).

Mazey, S. (1994) The Europeanisation of French regional government (occasional papers), European Public Policy Institute, University of Warwick, 94/1.

Négrier, E. (1999) The changing role of French local government, West European Politics, 22(4), pp. 120-140.

Nicholls, W. (2005) Power and governance: metropolitan governance in France, Urban Studies, 42(4), pp. $783-800$.

Ongaro, E. (2010) The Napoleonic administrative tradition and public management reform in France, Greece, Italy, Portugal and Spain, in: M. Painter \& B. G. Peters (Eds) Tradition and Public Administration, pp. 174-189 (Basingstoke: Palgrave Macmillan).

Paasi, A. (2001) Europe as a social process and discourse: considerations of place, boundaries and identity, European Urban and Regional Studies, 8(91), pp. 13-18.

Palard, J. (1993) Structural and regional planning confronted with decentralization and European integration, Regional \& Federal Studies, 3(3), pp. 192-210.

Pasquier, R. (2005) 'Cognitive Europeanization' and the territorial effects of multilevel policy transfer: local development in French and Spanish regions, Regional \& Federal Studies, 15(3), pp. 295-310.

Pasquier, R. (2010) The French regions and the European Union: policy change and institutional stability, in: R. Scully \& R. Wyn Jones (Eds) Europe, Regions and European Regionalism, pp. 134-154 (Basingstoke: Palgrave Macmillan). 
Putnam, R. (2000) Bowling Alone: The Collapse and Revival of American Community (New York: Simon \& Schuster).

Rémond, B. (1998) Fin de l'état jacobin? (Paris: LGDJ).

Richardson, T. \& Olsen, O. (2003) Linking discourse and space: towards a cultural sociology of space in analysing spatial policy discourses, Urban Studies, 40(1), pp. 7-22.

Schmidt, V. (1990) Unblocking society by decree: the impact of governmental decentralization in France, Comparative Politics, 22(4), pp. 459-481.

Schmidt, V. (1991) Democratizing France: The Political and Administrative History of Decentralization (Cambridge: Cambridge University Press).

Stevens, A. (1979) Politicisation and cohesion in the French administration, in: V. Wright (Ed) Conflict and Consensus in France, pp. 68-80 (London: Frank Cass).

Thoenig, J. -C. (2005) Territorial administration and political control: decentralization in France, Public Administration, 83(3), pp. 685-708.

Warleigh, A. (2003) Spinning around: rethinking a 'Europe of the regions!' in the light of flexibility, Comparative European Politics, 1(1), pp. 49-66.

Wright, V. (Ed.) (1979) Conflict and Consensus in France (London: Frank Cass).

Wyn Jones, R. \& Scully, R. (2010) Introduction: Europe, regions and European regionalism, in: R. Scully \& R. Wyn Jones (Eds) Europe, Regions and European Regionalism, pp. 1-15 (Basingstoke: Palgrave Macmillan). 